\title{
Role of angiotensin-converting enzyme 2 in neurodegenerative diseases during the COVID-19 pandemic
}

Review

\author{
Zhenyu $\mathrm{Li}^{1,{ }^{*}}$, Xiaolin $\mathrm{Xu}^{2,{ }^{*}}$, Meiling Yang ${ }^{1}$, Jianping Feng ${ }^{1}$, Cunming Liu $^{1}$, Chun Yang $^{1}$ \\ ${ }^{1}$ Department of Anesthesiology and Perioperative Medicine, The First Affiliated Hospital of Nanjing Medical \\ University, Nanjing 210029, China \\ ${ }^{2}$ Department of Anesthesiology, Tongji Hospital, Tongji Medical College, Wuhan 430030, China \\ *Equal contribution
}

Correspondence to: Cunming Liu, Chun Yang; email: cunmingliu@njmu.edu.cn, chunyang@njmu.edu.cn

Keywords: angiotensin-converting enzyme 2, neurodegenerative diseases, the elderly, COVID-19

Received: June 17, 2020

Accepted: August 15, 2020

Published: November 10, 2020

Copyright: $(\subseteq 2020 \mathrm{Li}$ et al. This is an open access article distributed under the terms of the Creative Commons Attribution License (CC BY 3.0), which permits unrestricted use, distribution, and reproduction in any medium, provided the original author and source are credited.

\begin{abstract}
SARS-CoV-2 (severe acute respiratory syndrome coronavirus 2) uses the angiotensin-converting enzyme 2 (ACE2) receptor for infecting and spreading in humans. Studies have shown that the widespread expression of ACE2 in human tissues may be associated with organ function damage (e.g., lung, kidney, and stomach) in patients with coronavirus disease 2019 (COVID-19). However, in neurodegenerative diseases, whose pathogenesis is closely related to advanced age, ACE2 plays a neurotrophic and protective role by activating the ACE2/Ang-(1-7)/Mas axis, thus inhibiting cognitive impairment. Early reports have revealed that the elderly are more susceptible to COVID-19 and that elderly patients with COVID-19 have faster disease progression and higher mortality. Therefore, during the COVID-19 pandemic, it is crucial to understand the role of ACE2 in neurodegenerative diseases. In this paper, we review the relationship between COVID-19, neurodegenerative diseases, and ACE2, as well as provide recommendations for the protection of elderly patients with neurodegenerative diseases during the COVID-19 pandemic.
\end{abstract}

\section{INTRODUCTION}

The global community is currently in the prevention and control phase of coronavirus disease 2019 (COVID-19). The International Committee on Taxonomy of Viruses named the virus causing COVID-19 as severe acute respiratory syndrome coronavirus 2 (SARS-CoV-2). From December 2019, the COVID-19 outbreak has affected nearly 20 million individuals worldwide. The World Health Organization specifically classified as a "pandemic" [1].

Currently, the median age of COVID-19 patients is approximately 50 years old, with the majority being males. Most patients experience mild symptoms, whereas approximately $25 \%$ of patients have a severe course requiring intensive care [2]. By contrast, adolescents and children usually experience mild symptoms [2]. Although
SARS-CoV-2 leads to minor or mild flu-like symptoms in the majority of affected patients, it may cause severe, lethal complications, such as progressive pneumonia, acute respiratory distress syndrome, and organ failure, driven by inflammation and a cytokine storm syndrome [3]. The Case Fatality Rate (CFR) of COVID-19 varies greatly between regions and age groups.

The COVID-19 is associated with a high risk of morbidity and mortality, which are increased in older patients and those with select co-morbidities. Several articles have summarized the relationship between COVID-19 and various systemic diseases in the human body, such as cardiovascular diseases, kidney disease, and digestive tract diseases. However, the association with neurodegenerative diseases is incompletely elucidated. Therefore, the aim of this article is to review the relationship between COVID-19 and 
neurodegenerative diseases from the perspective of ACE2, which is an important member of the pathogenesis of the diseases, thereby providing recommendations for the protection of elderly patients with neurodegenerative diseases during the COVID-19 pandemic.

\section{The relationship between COVID-19 and ACE2}

The renin-angiotensin system (RAS) contain the classical angiotensin-converting enzyme/angiotensin II/angiotensin type 1 receptor (ACE/Ang II/AT1R) pathway and the counter-regulatory ACE2/Ang-(17)/Mas receptor pathway. The two pathways are important in the maintenance of homeostasis in the human body, and their imbalances could contribute to various diseases, such as kidney disease, hypertension, and cardiovascular disease $[4,5]$. ACE2 is a key component of, but does not activate, the ACE2/Ang-(17)/Mas receptor pathway of the RAS. It is widely expressed in human tissues, such as lung, kidney, small intestine, and heart [6,7]. There is an association between smoking and ACE2 expression, although deeper connections still need to be explored [8,9]. Like SARS-CoV, SARS-CoV-2 uses ACE2 as its receptor for infecting human respiratory epithelial cells [10]. The SARS-CoV-2 virus coat expresses the $\mathrm{S}$ (Spike) protein with a receptor-binding region that directly binds to the extracellular domain of ACE2 [11]. A recent study demonstrated that the affinity of the S protein of SARSCoV-2 to human ACE2 is even higher than that of SARS-CoV [12]. Because SARS-CoV-2 need to bind to the ACE2 receptor before entering the host cells, the distribution and expression of ACE2 may be critical for the target organ of the SARS-CoV-2 infection [10].

Several lines of evidence suggest that the binding of SARS-CoV-2 to the ACE2 receptor leads to ACE2 depletion. This inhibits the ACE2/Ang (1-7)/Mas receptor pathway and disrupts the balance of the RAS system. The result is aggravation of severe acute pneumonia and cardiovascular complications, such as myocardial injury, myocarditis, acute myocardial infarction, heart failure, and arrhythmia in patients with COVID-19 [13, 14]. ACE2 plays a critical role in the course of COVID-19. It is not only a receptor but is also involved in post-infection regulation, including immune response, cytokine secretion, and viral genome replication [15]. Therefore, the target organs, which are prone to experience COVID-19 complications, have some consistency in the distribution and expression levels of the ACE2 receptor.

It has been well recognized that ACE2 plays a key role in SARS-CoV-2 infection. Therefore, some researchers have suggested that it is a potential therapeutic target for COVID-19. Recently, scientists from Spain, Sweden, and Canada, proposed to use recombinant human ACE2 (rhACE2) to "neutralize" COVID-19 to prevent it from entering human cells and causing infection. This new idea for the prevention of SARSCoV-2 infection focused on the early stage of viral infection, whereas this is theoretical and has not been validated in human [16]. In summary, potential COVID-19 therapies need to be further explored, and whether blocking ACE2 is a feasible way to relieve COVID-19 remains to be determined (Figure 1).

\section{Relationship between ACE2 and neurodegenerative diseases}

Neurodegenerative diseases are caused by the loss of neurons or their myelin sheaths. These diseases are common in the elderly and include Alzheimer's disease (AD), Parkinson's disease (PD), Huntington's disease, and multiple sclerosis (MS). The pathological manifestations of AD include abnormal accumulation of amyloid- $\beta$ (A $\beta)$ in the brain and aggregation of hyperphosphorylated tau-like proteins in neurons to form nerve fiber tangles [17]. The typical PD features are the pervasive presence of alpha-synuclein-positive Lewy bodies, loss of dopamine neurons, and dystrophic Lewy neurites [18].

RAS also plays an indispensable role in brain function, and studies have demonstrated that renin, ACE, Ang II, and Ang (1-7) are all found in the central nervous system. They participate in the blood pressure regulation, water and food intake, maintenance of the blood-brain barrier, and even movement, learning, memory, and emotional control [19]. Genetics, epidemiology, and clinical data all indicate that overactivation of the RAS system is one of the major elements in the pathogenesis of neurodegenerative diseases [19]. Furthermore, ACE2, including the ACE2/Ang (1-7)/Mas axis, plays a regulatory role in neurodegenerative diseases [20]. RAS dysregulation is related to the pathogenesis of $\mathrm{AD}$, and drugs targeting the RAS can improve cognitive impairment and AD [21-23]. Additionally, the level of ACE was decreased in the cerebrospinal fluid of $\mathrm{AD}$ patients, and it was negatively correlated with the level of $\mathrm{A} \beta[24,25]$. Moreover, electron microscopy revealed that ACE could delay fiber formation in a dose-dependent manner and reduce susceptibility to AD [26]. The amyloid deposited in the brain of $A D$ patients mainly refers to the longer and neurotoxic $A \beta 42$ and $A \beta 43$ [27]. ACE, a neuroprotective factor, can transform $\mathrm{A} \beta 42$ to the shorter and less neurotoxic $A \beta 40$ in the brain of amyloid precursor protein transgenic mice. ACE2, the homologue of ACE, functions as a powerful negative 
regulator in the RAS, balancing the multiple functions of ACE. Similarly, ACE2 can convert A $\beta 43$ to A $\beta 42$, and the combined use of ACE and ACE2 can convert $A \beta 43$ to $A \beta 40$ [27]. In a preclinical model experiment of AD, ACE2 was shown to prevent and reverse the pathological changes and cognitive impairment associated with amyloid in the hippocampus [28]. PI3K/Akt, an intracellular signaling pathway, can be regulated by the activation of the ACE2/Ang(1-7)/Mas axis, which can exert neuroprotective, anti-apoptotic, anti-inflammatory, and neurotrophic effects and can inhibit cognitive deficits in AD [29]. Most importantly, ACE2 was found in the brain tissue of AD patients after death. It was mainly distributed in the endothelial cells and smooth muscle cells of cerebral arteries, but ACE2 activity was reduced, and the ACE2/Ang (1-7)/Mas axis was imbalanced. Collectively, these findings further confirmed that therapeutic strategies activating ACE2 signaling has a potential to exert protective effects for $\mathrm{AD}[30]$.

ACE and ACE2 have also been detected in the cerebrospinal fluid of patients with PD and MS. Zubenko et al. detected a decrease in the ACE level in the cerebrospinal fluid of PD patients [31], and that Kawajiri et al. detected a decrease in the levels of ACE and ACE2 in the cerebrospinal fluid of MS patients [32]. However, there are few studies on the role of ACE2 in the pathological processes of PD and MS, and the specific mechanism needs to be explored (Figure 2).

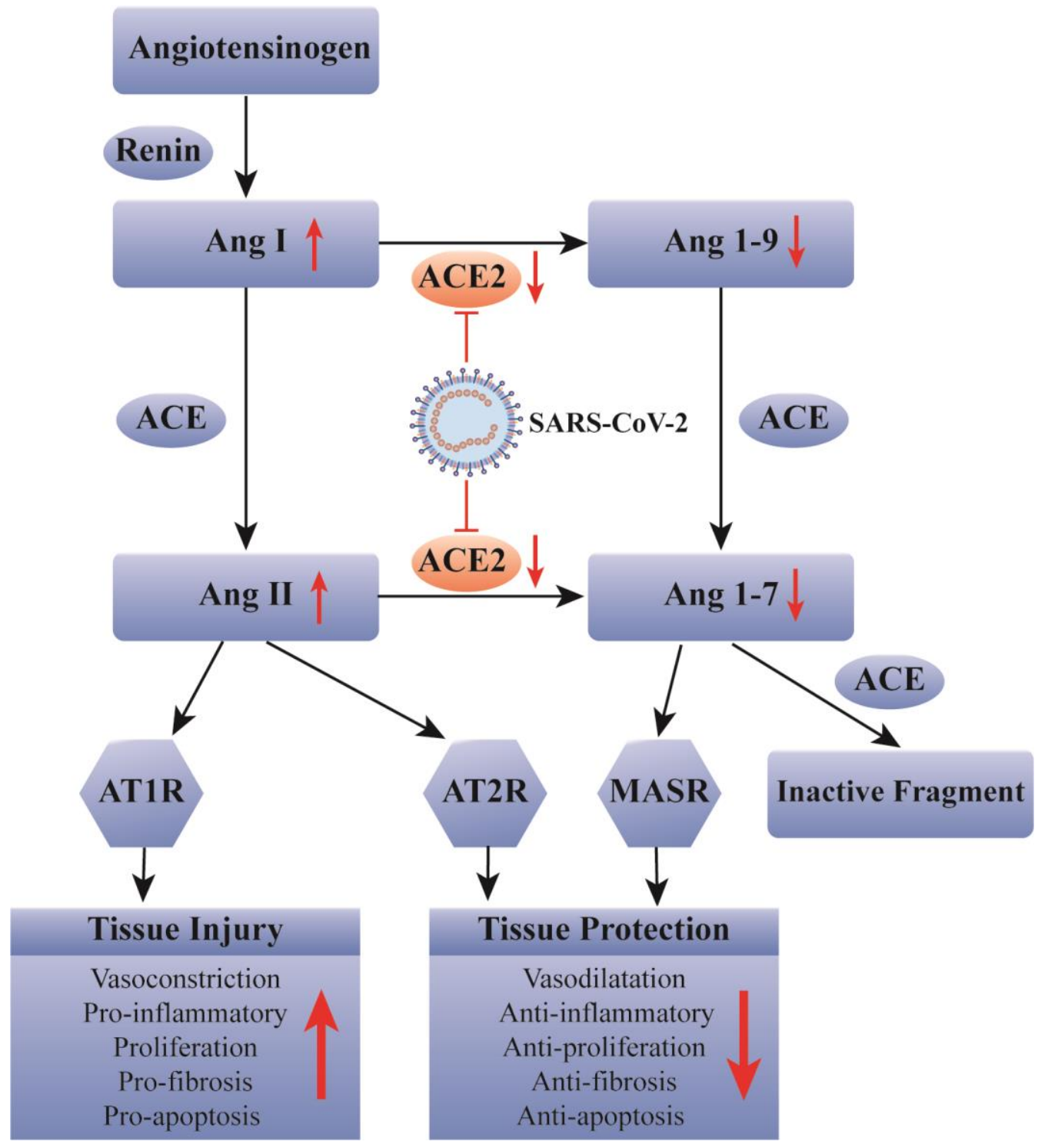

Figure 1. SARS-CoV-2 affects the renin-angiotensin system via ACE2. ACE: angiotensin converting enzyme; Ang: angiotensin; AT1R: Ang II type 1 receptor; AT2R: Ang II type 2 receptor; MASR: MAS receptor. 


\section{Neurodegenerative diseases and the elderly}

In 2013, the US official statistics recorded 84,767 deaths due to $\mathrm{AD}$ which is the $5^{\text {th }}$ leading cause of death for Americans over 65. In 2016, an estimated 700,000 Americans over the age of 65 died of AD [33]. In 2015, the number of patients with PD is 6.9 million worldwide, and it is expected to reach 14.2 million by 2040 with a strong age dependence [34]. Various pathological changes occur in neurodegenerative diseases, such as oxidative stress, immune inflammation, neurotoxicity, and mitochondrial dysfunction [35-37]. However, the main risk factor is still advanced age [38]. In addition, both hereditary and non-hereditary neurodegenerative diseases are similar in the age of onset and are part of the aging process [39]. Advanced age is often accompanied by a gradual decline in physiological function, and the pathophysiological changes related to old age also increase the risk of neurodegenerative diseases [40]. Elderly individuals often have chronic diseases, such as hypertension, and atherosclerosis has become a common phenomenon. Unfortunately, atherosclerosis and the accumulation of hypoperfusion-related vascular factors increase the risk of AD in the elderly [41]. The neural regeneration ability of the human brain declines rapidly with age [42], accompanied by cognitive impairment, which causes neurodegenerative diseases, such as $\mathrm{AD}$ and PD [43]. Dopamine systems in both human and rodent brains exhibit age-related presynaptic and postsynaptic decline. Even without neurological disease,

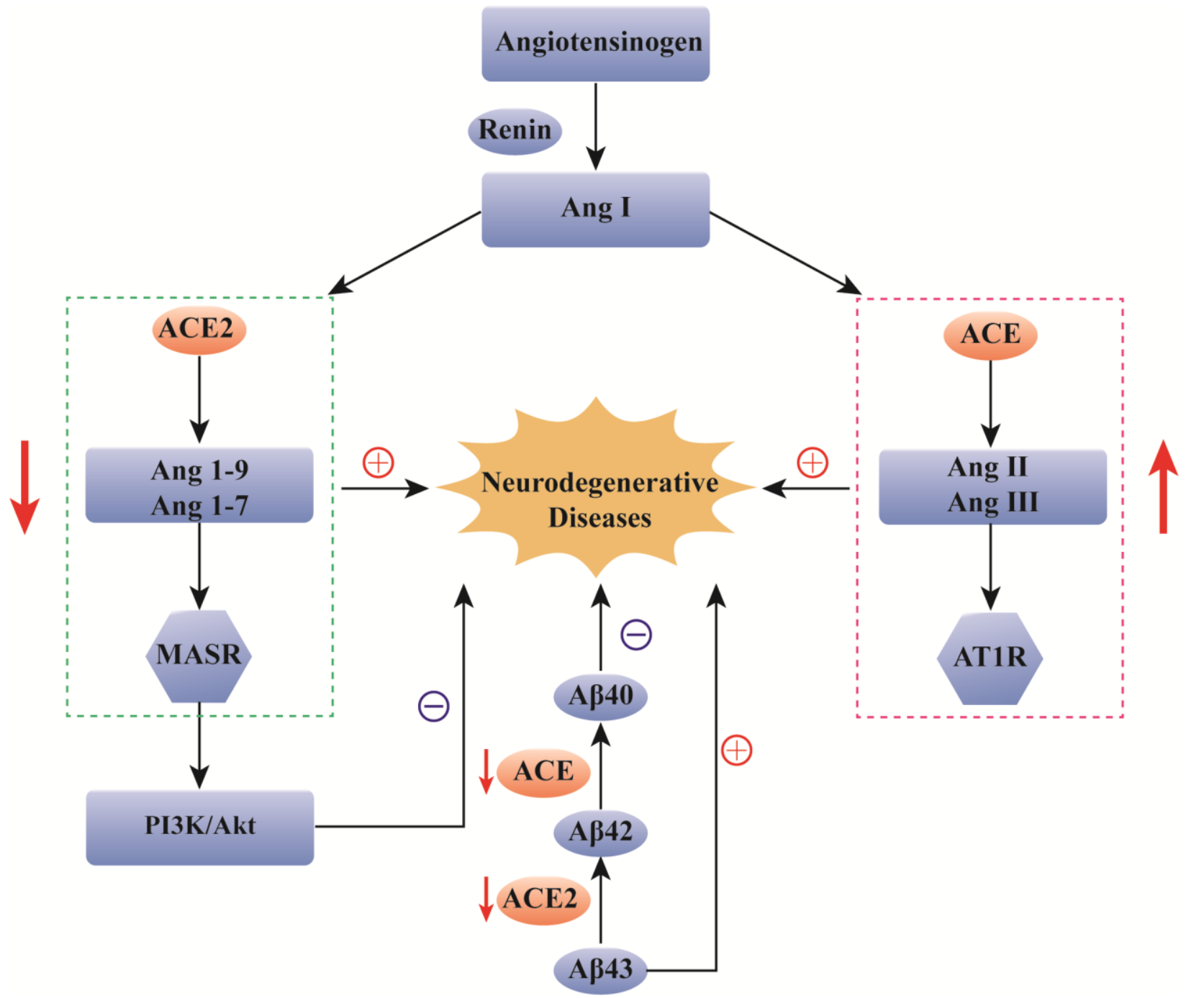

Figure 2. The role of ACE2 in neurodegenerative diseases. Reduction of ACE2 and ACE levels has been found in many neurodegenerative diseases, such as AD, PD and MS. The over-activation of ACE/Ang2/AT1 pathway and the imbalance of ACE2/Ang(17)/Mas pathway have been found to be closely related to the occurrence of AD. In addition, ACE2/Ang(1-7)/Mas pathway can alleviate the symptoms of $A D$ by regulating the PI3K/Akt signaling pathway. ACE and ACE2 are also involved in the transformation of $A \beta$ protein in $A D$ patients. ACE: angiotensin converting enzyme; Ang: angiotensin; AT1R: Ang II type 1 receptor; A $\beta$ : amyloid- $\beta$; MASR: MAS receptor. 
the number of dopamine neurons and dopamine levels of middle-aged individuals will have declined by $50 \%$ by the time they are elderly [43]. A previous study reported that neural stem cells (NSCs) were derived from the SVZ on postnatal $7 \mathrm{~d}, 1 \mathrm{~m}$, and $12 \mathrm{~m}$-old mice. Quantitative proteomic analysis of age-related subventricular zone proteins in mice revealed that the proliferative capacity of neural stem cells decreased with age [44].

\section{The elderly and COVID-19}

During the COVID-19 pandemic, the elderly have been at increased risk for morbidity and mortality, and it is becoming a huge challenge for the global health system $[45,46]$. The Centers for Disease Control and Prevention has reported that although people over 65 years old account for $17 \%$ of the population of the United States, they account for $31 \%$ of COVID-19 infections, $45 \%$ of hospitalizations, $53 \%$ of intensive care unit admissions, and $80 \%$ of deaths [47]. In China, even when public health measures are strictly enforced, people over the age of 60 account for $80 \%$ of deaths [48]. The elderly living in communities, nursing homes, assisted living facilities, and other communal living environments were reported to be at a high risk [49]. To reduce the mortality, UK has proposed the isolation of people over 70 years old, whereas the WHO has recommended a threshold of 60 years old. Some people have even called for elderly medical workers to avoid to be the epidemic prevention frontline workers [50]. Laboratory and imaging examinations have shown that the proportion of increased leukocytes and neutrophils, the proportion of decreased lymphocytes, and the incidence of multilobular lesions of the lungs in elderly patients were all higher than those in middle-aged patients [50]. A study revealed that in Wuhan, comorbidities, duration from paroxysm to hospitalization, renal dysfunction, and elevated procalcitonin levels were significantly associated with higher death rates in the elderly $(>65$ years) [51].

The symptoms of COVID-19 in the elderly are often atypical such as delirium, low-grade fever, and abdominal pain [52, 53], which undoubtedly hinders early diagnosis and timely treatment and prolongs the onset of hospitalization. A survey of 21 patients with an average age of 70 years in Washington indicated that SARS-CoV-2 infection resulted in various forms of organ damage, including acute respiratory distress syndrome $(71 \%)$, acute kidney injury $(20 \%)$, heart injury (33\%), and liver dysfunction (15\%) [54]. In addition, the elderly experience age-related immunosenescence, such as thymus degeneration and bone marrow dysfunction. These affect the cellular and molecular elements of innate and adaptive immunity, thus weakening the immune system. Consequently, elderly individuals are easily infected and vulnerable to death due to comorbid diseases [55]. Clinical data reveal that the average number of days from the first symptom to death for people over 70 years old (about 11.5 days) is shorter than that of younger people (20 days), suggesting that the disease progresses more rapidly in elderly individuals [56]. Regardless of environmental or physiological conditions, the elderly are more easily infected with COVID-19 and are more likely to die.

\section{Protective measures}

ACE2, which is associated with improvements in neurodegenerative diseases, is the viral receptor that facilitates the entry of the virus into human cells. Thus, during this pandemic, the elderly with neurodegenerative diseases are at risk, and strengthening the attention and protection of these patients is important. However, since there is no vaccine or specific antiviral drug for COVID19 , the best way is to avoid exposure to the virus. Elderly people with a neurodegenerative disease should be advised to self-isolate at home. To protect the elderly and thus relieve overburdened health systems, countries around the world have begun to implement blockades and quarantine measures to reduce the spread of SARSCoV-2.

\section{Abbreviations}

$\mathrm{A} \beta$ : amyloid- $\beta$; ACE2: angiotensin-converting enzyme 2; AD: alzheimer's disease; Ang: angiotensin; AT1R: angiotensin type 1 receptor; CFR: case fatality rate; COVID-19: coronavirus disease 2019; MS: multiple sclerosis; NSCs: neural stem cells; PD: parkinson's disease; RAS: renin-angiotensin system; rhACE2: recombinant human angiotensin-converting enzyme 2; SARS-CoV-2: severe acute respiratory syndrome coronavirus 2; S: spike.

\section{AUTHOR CONTRIBUTIONS}

Concept and design: Z. Li, X. Xu, C. Liu, C. Yang; Drafting of the manuscript: Z. Li, X. Xu, C. Yang; Critical revision of the manuscript: Z. Li, X. Xu, M. Yang, J. Feng, C. Liu, C. Yang; Supervision: C. Liu, C. Yang.

\section{CONFLICTS OF INTEREST}

All authors declare no potential conflicts of interest.

\section{FUNDING}

This work was supported by grants from the National Natural Science Foundation of China (grant numbers: 81703482 and 81974171 to C. Y.). 


\section{REFERENCES}

1. Cucinotta D, Vanelli M. WHO declares COVID-19 a pandemic. Acta Biomed. 2020; 91:157-60. https://doi.org/10.23750/abm.v91i1.9397 PMID: 32191675

2. Del Rio C, Malani PN. COVID-19-new insights on a rapidly changing epidemic. JAMA. 2020. 323:1339-40. https://doi.org/10.1001/jama.2020.3072 PMID: $\underline{32108857}$

3. Neurath MF. COVID-19 and immunomodulation in IBD. Gut. 2020; 69:1335-42. https://doi.org/10.1136/gutjnl-2020-321269 PMID:32303609

4. Mizuiri S, Ohashi Y. ACE and ACE2 in kidney disease. World J Nephrol. 2015; 4:74-82. https://doi.org/10.5527/wjn.v4.i1.74 PMID:25664248

5. Burrell LM, Harrap SB, Velkoska E, Patel SK. The ACE2 gene: its potential as a functional candidate for cardiovascular disease. Clin Sci (Lond). 2013; 124:65-76.

https://doi.org/10.1042/CS20120269 PMID:23013041

6. Jia H. Pulmonary angiotensin-converting enzyme 2 (ACE2) and inflammatory lung disease. Shock. 2016; 46:239-48.

https://doi.org/10.1097/SHK.0000000000000633 PMID:27082314

7. Anguiano L, Riera M, Pascual J, Soler MJ. Circulating ACE2 in cardiovascular and kidney diseases. Curr Med Chem. 2017; 24:3231-41. https://doi.org/10.2174/092986732466617041416284 1 PMID: $\underline{28413960}$

8. Leung JM, Yang CX, Tam A, Shaipanich T, Hackett TL, Singhera GK, Dorscheid DR, Sin DD. ACE-2 expression in the small airway epithelia of smokers and COPD patients: implications for COVID-19. Eur Respir J. 2020; 55:2000688.

https://doi.org/10.1183/13993003.00688-2020 PMID:32269089

9. Brake SJ, Barnsley K, Lu W, McAlinden KD, Eapen MS, Sohal SS. Smoking upregulates angiotensin-converting enzyme-2 receptor: a potential adhesion site for novel coronavirus SARS-CoV-2 (Covid-19). J Clin Med. 2020; 9:841.

https://doi.org/10.3390/jcm9030841 PMID:32244852

10. Lan J, Ge J, Yu J, Shan S, Zhou H, Fan S, Zhang Q, Shi X, Wang $Q$, Zhang L, Wang X. Structure of the SARS-CoV-2 spike receptor-binding domain bound to the ACE2 receptor. Nature. 2020; 581:215-20. https://doi.org/10.1038/s41586-020-2180-5 PMID:32225176
11. Liu Z, Xiao X, Wei X, Li J, Yang J, Tan H, Zhu J, Zhang Q, Wu J, Liu L. Composition and divergence of coronavirus spike proteins and host ACE2 receptors predict potential intermediate hosts of SARS-CoV-2. J Med Virol. 2020; 92:595-601. https://doi.org/10.1002/jmv.25726 PMID:32100877

12. Wrapp D, Wang N, Corbett KS, Goldsmith JA, Hsieh CL, Abiona O, Graham BS, McLellan JS. cryo-EM structure of the 2019-nCoV spike in the prefusion conformation. Science. 2020; 367:1260-63.

https://doi.org/10.1126/science.abb2507 PMID: $\underline{32075877}$

13. Hanff TC, Harhay MO, Brown TS, Cohen JB, Mohareb AM. Is there an association between COVID-19 mortality and the renin-angiotensin system? a call for epidemiologic investigations. Clin Infect Dis. 2020; 71:870-74.

https://doi.org/10.1093/cid/ciaa329 PMID:32215613

14. Long B, Brady WJ, Koyfman A, Gottlieb M. Cardiovascular complications in COVID-19. Am J Emerg Med. 2020; 38:1504-07.

https://doi.org/10.1016/i.ajem.2020.04.048 PMID:32317203

15. Michaud V, Deodhar M, Arwood M, Al Rihani SB, Dow $P$, Turgeon J. ACE2 as a therapeutic target for COVID19; its role in infectious processes and regulation by modulators of the RAAS system. J Clin Med. 2020; 9:2096. https://doi.org/10.3390/jcm9072096 PMID:32635289

16. Gheblawi M, Wang K, Viveiros A, Nguyen $Q$, Zhong JC, Turner AJ, Raizada MK, Grant MB, Oudit GY. Angiotensin-converting enzyme 2: SARS-CoV-2 receptor and regulator of the renin-angiotensin system: celebrating the 20th anniversary of the discovery of ACE2. Circ Res. 2020; 126:1456-74. https://doi.org/10.1161/CIRCRESAHA.120.317015 PMID:32264791

17. Morrone CD, Bishay J, McLaurin J. Potential role of venular amyloid in Alzheimer's disease pathogenesis. Int J Mol Sci. 2020; 21:1985.

https://doi.org/10.3390/ijms21061985

PMID:32183293

18. Leroy E, Boyer R, Auburger G, Leube B, Ulm G, Mezey E, Harta G, Brownstein MJ, Jonnalagada S, Chernova T, Dehejia A, Lavedan C, Gasser T, et al. The ubiquitin pathway in Parkinson's disease. Nature. 1998; 395:451-52.

https://doi.org/10.1038/26652

PMID: $\underline{9774100}$

19. Paul M, Poyan Mehr A, Kreutz R. Physiology of local renin-angiotensin systems. Physiol Rev. 2006; 86:747-803. 
https://doi.org/10.1152/physrev.00036.2005 PMID:16816138

20. Kaur P, Muthuraman A, Kaur M. The implications of angiotensin-converting enzymes and their modulators in neurodegenerative disorders: current and future perspectives. ACS Chem Neurosci. 2015; 6:508-21. https://doi.org/10.1021/cn500363g PMID:25680080

21. Li NC, Lee A, Whitmer RA, Kivipelto M, Lawler E, Kazis LE, Wolozin B. Use of angiotensin receptor blockers and risk of dementia in a predominantly male population: prospective cohort analysis. BMJ. 2010; 340:b5465.

https://doi.org/10.1136/bmj.b5465 PMID:20068258

22. Ongali B, Nicolakakis N, Tong XK, Aboulkassim $T$, Papadopoulos P, Rosa-Neto P, Lecrux C, Imboden $\mathrm{H}$, Hamel E. Angiotensin II type 1 receptor blocker losartan prevents and rescues cerebrovascular, neuropathological and cognitive deficits in an Alzheimer's disease model. Neurobiol Dis. 2014; 68:126-36.

https://doi.org/10.1016/i.nbd.2014.04.018 PMID:24807206

23. Ohrui T, Tomita N, Sato-Nakagawa T, Matsui T, Maruyama M, Niwa K, Arai H, Sasaki H. Effects of brainpenetrating ACE inhibitors on Alzheimer disease progression. Neurology. 2004; 63:1324-5.

https://doi.org/10.1212/01.wnl.0000140705.23869.e9 PMID:15477567

24. Rocha NP, Toledo A, Corgosinho LT, de Souza LC, Guimarães HC, Resende EP, Braz NF, Gomes KB, Simoes E Silva AC, Caramelli P, Teixeira AL. Cerebrospinal fluid levels of angiotensin-converting enzyme are associated with amyloid- $\beta 42$ burden in Alzheimer's disease. J Alzheimers Dis. 2018; 64:1085-90.

https://doi.org/10.3233/JAD-180282

PMID:30040721

25. Jochemsen HM, Teunissen $\mathrm{CE}$, Ashby EL, van der Flier WM, Jones RE, Geerlings MI, Scheltens P, Kehoe PG, Muller $\mathrm{M}$. The association of angiotensin-converting enzyme with biomarkers for Alzheimer's disease. Alzheimers Res Ther. 2014; 6:27.

https://doi.org/10.1186/alzrt257 PMID:24987467

26. Hu J, Igarashi A, Kamata M, Nakagawa H. Angiotensinconverting enzyme degrades Alzheimer amyloid betapeptide (A beta); retards a beta aggregation, deposition, fibril formation; and inhibits cytotoxicity. J Biol Chem. 2001; 276:47863-68. https://doi.org/10.1074/ibc.M104068200 PMID:11604391

27. Zou K, Liu J, Watanabe A, Hiraga S, Liu S, Tanabe C, Maeda T, Terayama Y, Takahashi S, Michikawa M,
Komano $H . A \beta 43$ is the earliest-depositing $A \beta$ species in APP transgenic mouse brain and is converted to A 411 by two active domains of ACE. Am J Pathol. 2013; 182:2322-31.

https://doi.org/10.1016/i.ajpath.2013.01.053 PMID:23562443

28. Evans CE, Miners JS, Piva G, Willis CL, Heard DM, Kidd EJ, Good MA, Kehoe PG. ACE2 activation protects against cognitive decline and reduces amyloid pathology in the Tg2576 mouse model of Alzheimer's disease. Acta Neuropathol. 2020; 139:485-502. https://doi.org/10.1007/s00401-019-02098-6 PMID:31982938

29. Kamel AS, Abdelkader NF, Abd El-Rahman SS, Emara M, Zaki HF, Khattab MM. Stimulation of ACE2/ANG(17)/mas axis by diminazene ameliorates Alzheimer's disease in the D-Galactose-ovariectomized rat model: role of PI3K/Akt pathway. Mol Neurobiol. 2018; 55:8188-202.

https://doi.org/10.1007/s12035-018-0966-3 PMID:29516284

30. Kehoe PG, Wong S, Al Mulhim N, Palmer LE, Miners JS. Angiotensin-converting enzyme 2 is reduced in Alzheimer's disease in association with increasing amyloid- $\beta$ and tau pathology. Alzheimers Res Ther. 2016; 8:50.

https://doi.org/10.1186/s13195-016-0217-7 PMID:27884212

31. Zubenko GS, Volicer L, Direnfeld LK, Freeman M, Langlais PJ, Nixon RA. Cerebrospinal fluid levels of angiotensin-converting enzyme in Alzheimer's disease, Parkinson's disease and progressive supranuclear palsy. Brain Res. 1985; 328:215-21.

https://doi.org/10.1016/0006-8993(85)91032-7 PMID:2985183

32. Kawajiri $M$, Mogi $M$, Higaki $N$, Matsuoka $T$, Ohyagi $Y$, Tsukuda K, Kohara K, Horiuchi M, Miki T, Kira Jl. Angiotensin-converting enzyme (ACE) and ACE2 levels in the cerebrospinal fluid of patients with multiple sclerosis. Mult Scler. 2009; 15:262-65. https://doi.org/10.1177/1352458508097923 PMID:19136547

33. Alzheimer's Association. 2016 Alzheimer's disease facts and figures. Alzheimers Dement. 2016; 12:459-509. https://doi.org/10.1016/i.jalz.2016.03.001 PMID:27570871

34. Blauwendraat $\mathrm{C}$, Heilbron $\mathrm{K}$, Vallerga CL, Bandres-Ciga $S$, von Coelln R, Pihlstrøm L, Simón-Sánchez J, Schulte C, Sharma M, Krohn L, Siitonen A, Iwaki H, Leonard H, et al, and 23andMe Research Team, and International Parkinson's Disease Genomics Consortium (IPDGC). Parkinson's disease age at onset genome-wide association study: defining heritability, genetic loci, 
and $\alpha$-synuclein mechanisms. Mov Disord. 2019; 34:866-75.

https://doi.org/10.1002/mds.27659

PMID:30957308

35. Lopes KO, Sparks DL, Streit WJ. Microglial dystrophy in the aged and Alzheimer's disease brain is associated with ferritin immunoreactivity. Glia. 2008; 56:1048-60. https://doi.org/10.1002/glia.20678 PMID:18442088

36. Peng Y, Gao P, Shi L, Chen L, Liu J, Long J. Central and peripheral metabolic defects contribute to the pathogenesis of Alzheimer's disease: targeting mitochondria for diagnosis and prevention. Antioxid Redox Signal. 2020; 32:1188-236.

https://doi.org/10.1089/ars.2019.7763

PMID:32050773

37. Feldman RG, Ratner $\mathrm{MH}$. The pathogenesis of neurodegenerative disease: neurotoxic mechanisms of action and genetics. Curr Opin Neurol. 1999; 12:725-31.

https://doi.org/10.1097/00019052-199912000-00012 PMID:10676756

38. Robinson JL, Lee EB, Xie SX, Rennert L, Suh E, Bredenberg C, Caswell C, Van Deerlin VM, Yan N, Yousef A, Hurtig HI, Siderowf A, Grossman $M$, et al. Neurodegenerative disease concomitant proteinopathies are prevalent, age-related and APOE4associated. Brain. 2018; 141:2181-93.

https://doi.org/10.1093/brain/awy146 PMID:29878075

39. Ridley RM, Baker HF, Crow TJ. Transmissible and nontransmissible neurodegenerative disease: similarities in age of onset and genetics in relation to aetiology. Psychol Med. 1986; 16:199-207.

https://doi.org/10.1017/s0033291700002634 PMID: $\underline{3961045}$

40. Jucker M, Ingram DK. Age-related fibrillar material in mouse brain. Assessing its potential as a biomarker of aging and as a model of human neurodegenerative disease. Ann N Y Acad Sci. 1994; 719:238-47. https://doi.org/10.1111/j.1749-6632.1994.tb56832.x PMID:이요

41. Qiu C, Xu W, Winblad B, Fratiglioni L. Vascular risk profiles for dementia and Alzheimer's disease in very old people: a population-based longitudinal study. J Alzheimers Dis. 2010; 20:293-300. https://doi.org/10.3233/JAD-2010-1361 PMID:20164587

42. Della-Maggiore V, Grady CL, Mclntosh AR. Dissecting the effect of aging on the neural substrates of memory: deterioration, preservation or functional reorganization? Rev Neurosci. 2002; 13:167-81. https://doi.org/10.1515/revneuro.2002.13.2.167 PMID:12160260

43. Winner B, Kohl Z, Gage FH. Neurodegenerative disease and adult neurogenesis. Eur J Neurosci. 2011; 33:1139-51.

https://doi.org/10.1111/i.1460-9568.2011.07613.x PMID:21395858

44. Wang X, Dong C, Sun L, Zhu L, Sun C, Ma R, Ning K, Lu $B$, Zhang J, Xu J. Quantitative proteomic analysis of age-related subventricular zone proteins associated with neurodegenerative disease. Sci Rep. 2016; 6:37443. https://doi.org/10.1038/srep37443 PMID:27857231

45. Schrack JA, Wanigatunga AA, Juraschek SP. After the COVID-19 pandemic: the next wave of health challenges for older adults. J Gerontol A Biol Sci Med Sci. 2020. 75:e121-e122. https://doi.org/10.1093/gerona/glaa102 PMID: $\underline{32315025}$

46. Glynn JR. Protecting workers aged 60-69 years from COVID-19. Lancet Infect Dis. 2020; 20:1123. https://doi.org/10.1016/S1473-3099(20)30311-X PMID:32305069

47. Shahid Z, Kalayanamitra R, McClafferty B, Kepko D, Ramgobin D, Patel R, Aggarwal CS, Vunnam R, Sahu N, Bhatt D, Jones K, Golamari R, Jain R. COVID-19 and older adults: what we know. J Am Geriatr Soc. 2020; 68:926-29. https://doi.org/10.1111/jgs.16472 PMID:32255507

48. Osama T, Pankhania B, Majeed A. Protecting older people from COVID-19: should the United Kingdom start at age 60? J R Soc Med. 2020; 113:169-70. https://doi.org/10.1177/0141076820921107 PMID:32315559

49. Applegate WB, Ouslander JG. COVID-19 presents high risk to older persons. J Am Geriatr Soc. 2020; 68:681. https://doi.org/10.1111/jgs.16426 PMID:32154911

50. Ashcroft J. Keep older healthcare workers off the covid-19 front line. BMJ. 2020; 369:m1511.

https://doi.org/10.1136/bmj.m1511 PMID:32303493

51. Chen T, Dai Z, Mo P, Li X, Ma Z, Song S, Chen X, Luo M, Liang K, Gao S, Zhang Y, Deng L, Xiong Y. Clinical characteristics and outcomes of older patients with coronavirus disease 2019 (COVID-19) in Wuhan, China (2019): a single-centered, retrospective study. J Gerontol A Biol Sci Med Sci. 2020; 75:1788-1795. https://doi.org/10.1093/gerona/glaa089 PMID:32279081

52. Tay HS, Harwood R. Atypical presentation of COVID-19 in a frail older person. Age Ageing. 2020; 49:523-24. 
https://doi.org/10.1093/ageing/afaa068

PMID:32315386

53. Godaert L, Proye E, Demoustier-Tampere D, Coulibaly PS, Hequet F, Dramé M. Clinical characteristics of older patients: the experience of a geriatric short-stay unit dedicated to patients with COVID-19 in France. J Infect. 2020; 81:e93-94.

https://doi.org/10.1016/i.jinf.2020.04.009

PMID:32305489

54. Arentz M, Yim E, Klaff L, Lokhandwala S, Riedo FX, Chong $M$, Lee $M$. Characteristics and outcomes of 21 critically ill patients with COVID-19 in Washington state. JAMA. 2020; 323:1612-14. https://doi.org/10.1001/jama.2020.4326 PMID:32191259
55. Nikolich-Zugich J, Knox KS, Rios CT, Natt B, Bhattacharya D, Fain MJ. SARS-CoV-2 and COVID-19 in older adults: what we may expect regarding pathogenesis, immune responses, and outcomes. Geroscience. 2020; 42:505-14.

https://doi.org/10.1007/s11357-020-00186-0

PMID: $\underline{2274617}$

56. Garnier-Crussard A, Forestier E, Gilbert T, KrolakSalmon P. Novel coronavirus (COVID-19) epidemic: what are the risks for older patients? J Am Geriatr Soc. 2020; 68:939-40.

https://doi.org/10.1111/igs.16407

PMID:32162679 